\title{
Ice nucleation by combustion ash particles at conditions relevant to mixed-phase clouds
}

\author{
N. S. Umo ${ }^{1}$, B. J. Murray ${ }^{1}$, M. T. Baeza-Romero ${ }^{2}$, J. M. Jones ${ }^{3}$, A. R. Lea-Langton ${ }^{3}$, T. L. Malkin ${ }^{1}$, D. O’Sullivan ${ }^{1}$, \\ L. Neve ${ }^{1}$, J. M. C. Plane ${ }^{4}$, and A. Williams ${ }^{3}$ \\ ${ }^{1}$ Institute for Climate and Atmospheric Science, School of Earth and Environment, University of Leeds, Leeds, LS2 9JT, UK \\ ${ }^{2}$ Escuela de Ingeniería Industrial de Toledo, Universidad de Castilla la Mancha, Avenida Carlos III s/n, \\ Real Fábrica de Armas, 45071 Toledo, Spain \\ ${ }^{3}$ Energy Research Institute/CFD Centre, Faculty of Engineering, University of Leeds, Leeds, LS2 9JT, UK \\ ${ }^{4}$ School of Chemistry, University of Leeds, Leeds, LS2 9JT, UK
}

Correspondence to: N. S. Umo (eensu@ leeds.ac.uk) and B. J. Murray (b.j.murray@leeds.ac.uk)

Received: 28 October 2014 - Published in Atmos. Chem. Phys. Discuss.: 19 November 2014

Revised: 20 April 2015 - Accepted: 21 April 2015 - Published: 11 May 2015

\begin{abstract}
Ice-nucleating particles can modify cloud properties with implications for climate and the hydrological cycle; hence, it is important to understand which aerosol particle types nucleate ice and how efficiently they do so. It has been shown that aerosol particles such as natural dusts, volcanic ash, bacteria and pollen can act as ice-nucleating particles, but the ice-nucleating ability of combustion ashes has not been studied. Combustion ashes are major by-products released during the combustion of solid fuels and a significant amount of these ashes are emitted into the atmosphere either during combustion or via aerosolization of bottom ashes. Here, we show that combustion ashes (coal fly ash, wood bottom ash, domestic bottom ash, and coal bottom ash) nucleate ice in the immersion mode at conditions relevant to mixed-phase clouds. Hence, combustion ashes could play an important role in primary ice formation in mixed-phase clouds, especially in clouds that are formed near the emission source of these aerosol particles. In order to quantitatively assess the impact of combustion ashes on mixed-phase clouds, we propose that the atmospheric abundance of combustion ashes should be quantified since up to now they have mostly been classified together with mineral dust particles. Also, in reporting ice residue compositions, a distinction should be made between natural mineral dusts and combustion ashes in order to quantify the contribution of combustion ashes to atmospheric ice nucleation.
\end{abstract}

\section{Introduction}

Combustion processes - either natural or anthropogenic are a major source of atmospheric aerosol particles (Bond et al., 2013; Li et al., 2003; Pósfai et al., 2003). Various combustion by-products are released directly or indirectly into the atmosphere. These include black and brown carbon, soot, ashes, tar balls, volatile organic compounds (VOCs), and other gases (Petters et al., 2009; Posfai et al., 2004; Fitzpatrick et al., 2008; Williams et al., 2012). These by-products can impact on air quality, health and visibility. Additionally, they can influence cloud properties and hence, the Earth's climate (Forster et al., 2007; Jacobson, 2014). These combustion particles can impact cloud properties by acting as cloud condensation nuclei (CCN) (Spracklen et al., 2011) and potentially as ice-nucleating particles (INPs) (Murray et al., 2012; Hoose and Möhler, 2012; Petters et al., 2009).

Ice nucleation can occur via various pathways: deposition nucleation entails formation of ice from water vapour onto a solid particle; contact freezing occurs when a particle comes in contact with an interface of a supercooled water droplet; immersion ice nucleation happens when a particle is fully immersed in a water droplet and freezes upon further cooling; condensation freezing is more poorly defined, but involves the condensation of water prior to freezing (Vali, 1985; Wex et al., 2014). Of these ice nucleation pathways, immersion mode is argued to be the dominant process for primary ice nucleation in mixed-phase clouds $\left(0\right.$ to $\left.-36^{\circ} \mathrm{C}\right)$ (Bond et al., 
2013; Murray et al., 2012; Ansmann et al., 2009); hence, we focus here on mixed-phase cloud conditions.

The ice nucleation abilities of some soot types (DeMott, 1990; Kireeva et al., 2009; Popovicheva et al., 2008) and emissions from controlled burns of a range of plant fuels (Petters et al., 2009) in the immersion/condensation mode have been reported, but there are no data on the ice nucleation activities of combustion ashes. Field studies have reported the presence of combustion ashes in atmospheric aerosols $(\mathrm{Li}$ and Shao, 2009; Li et al., 2011) and ice crystal residues (DeMott et al., 2003; Kumai, 1961; Cziczo et al., 2004) based on a combination of elemental composition and morphology analyses. However, the distinction between mineral dust and combustion ash is often not done because they have similar compositions.

There are similarities between the elemental composition of fly ash and mineral dust (Chen et al., 2012), which means that it is a challenge to distinguish them using mass spectrometry and other techniques. Consequently, many ice crystal residue studies attributed all mineral compositions to natural dusts although in part it could be due to fly ashes. It is therefore important for the contribution of combustion ashes to atmospheric INPs to be considered. Moreover, given that some mineral dusts are relatively good INPs and combustion ashes have some similarities in their elemental/mineral compositions, we initially hypothesized that combustion ashes have a comparable ice-nucleating efficiency to mineral dusts.

Combustion ashes can be classed into two groups: (1) bottom ashes - which are mainly the mineral remains of a complete combustion process, and (2) fly ashes - ash particles that are primarily emitted during combustion processes with further contributions from the smelting of metallurgical materials, sometimes directly into the atmosphere (Adriano et al., 1980; USEPA, 2012; Hu et al., 2013). While coal is a major source of fly ash in the atmosphere, biomass burning, wildfires and domestic combustion dominate the bottom ash emissions (Raison et al., 1985; Certini, 2005).

Coal fly ash is one of the major by-products of coal combustion from both household and power plants, used for the purpose of heating and generating electricity for industrial and domestic consumptions (ACCA, 2013; WCA, 2013; Mahlaba et al., 2012). There is increasing demand for coal to generate electricity around the globe. This has led to $\sim 8000$ million tonnes of coal being consumed daily in coalfired power plants which are distributed all over the world (WCA, 2013). It is estimated that about $90 \%$ of the fly ash is captured via different collection mechanisms such as electrostatic precipitators, fabric filters or bag houses, dust collectors, and other hybrid engineering systems like hot gas filtration systems (Bond et al., 2004; Wang et al., 2013; WCA, 2013). Nevertheless, sizeable quantities of these ash particles are emitted to the atmosphere as a result of inefficiencies associated with collection systems (e.g. electrostatic precipitators), during transportation and storage of collected fly ash (Block and Dams, 1976).

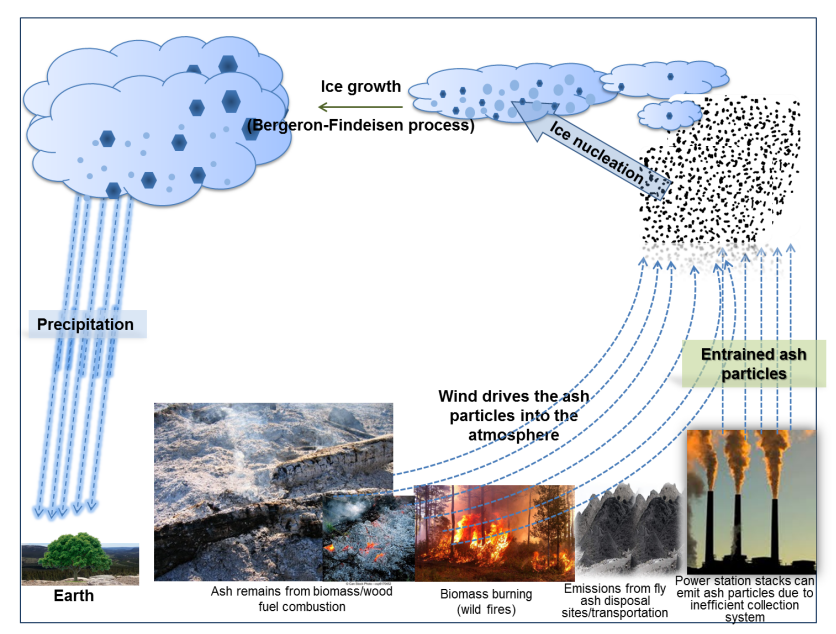

Figure 1. This schematic highlights the possible sources, emission routes and interactions of combustion ash particles in the troposphere. Combustion ash particles also participate in heterogeneous chemistry processes in the atmosphere. This study focuses on their ice nucleation activity at conditions relevant to mixed-phase clouds.

Bottom ashes include ashes from the combustion of wood, other biomass, peat, coal and charcoal solid fuels, and are produced during wildfires or bush-burning (agricultural practices) (Pereira and Úbeda, 2010), as well as in domestic and industrial settings (Chimenos et al., 1999). Bottom ashes can be lofted into the atmosphere via the action of wind sometime after the fire as well as during combustion (see Fig. 1). Compositional analyses of various ash samples from different sources have been investigated previously, and efforts have focused on the effect of these ashes on agricultural soils, applications in cement production and disposal methods (Adriano et al., 1980; Basumajumdar et al., 2005). However, little attention has been given to the potential effect of these particles on cloud properties when they are lofted into the atmosphere.

Combustion ash particles emitted may have direct and indirect impacts on the planet's climate analogous to other types of aerosol particles (Forster et al., 2007; Murray et al., 2012) (as illustrated in Fig. 1). Many studies have shown that particles in the atmosphere such as mineral dust, soot, volcanic ash, pollen, fungi and bacteria are INPs (Murray et al., 2012; Hoose and Möhler, 2012). Nevertheless, it is not known at present if combustion ashes nucleate ice.

There are some indications that combustion ashes could be important INPs. Recently, several tens of percent of ice crystal residues from both prescribed burns and wildfires were identified as carbonaceous-mineral and mineral-oxide mixed particles (McCluskey et al., 2014). The measurement was performed at activation temperatures of between -5 and $-23^{\circ} \mathrm{C}$ at water supersaturation (SSw) of $5( \pm 2.5) \%$ at each temperature. It is possible that the inorganic mineral particles may have come from the combustion ash components of 
the fires. This is in contrast to Schnell et al. (1976) who conducted an airborne study of INPs in a coal-fired power plant plume. They showed that plume particles did not act as INPs between -10 and $-20^{\circ} \mathrm{C}$ in the deposition or condensation mode, as no difference was observed between the background air and the plume. Conversely, a study on plume particles at a higher supersaturation with respect to ice showed an enhancement, by a factor of 2 , in the number of INPs in the plume when compared to natural aerosols (Parungo et al., 1978). In summary, these studies indicated that fly ash has some ice-nucleating potential, but there is no quantitative laboratory study of ice nucleation by combustion ashes in the immersion mode.

In this study, we first systematically characterized four types of combustion ashes obtained at well-defined conditions. We then quantify the ice nucleation activities of these particles in the immersion mode.

\section{Sources and generation of combustion ashes}

In order to study ashes with a range of compositions representative of typical combustion ashes, we have generated ashes in both a controlled laboratory environment and a domestic setting, as well as obtaining fly ash from a large commercial power station.

Bottom ash samples from wood and coal were generated in the laboratory using a fixed grate multi-fuel stove rated at $6.5 \mathrm{~kW}$ (BS EN 13240:2001 and A2:2004), which is used for efficient burning of solid fuels (e.g. wood or coal). The solid fuel was lit by using a commercially available standard firelighter and it burned at relatively low temperature $\left(\sim 800^{\circ} \mathrm{C}\right)$. This temperature is more typical of domestic stoves and wildfires and contrasts with high-temperature combustion systems in power plants $\left(\sim 1000^{\circ} \mathrm{C}\right.$ and above $)$. The ash samples were collected after the combustion process from the ash pan fixed at the bottom of the stove.

Wood solid fuel used in generating the bottom ash samples was a standard commercially available domestic fuel, while the coal solid fuel was also a domestic fuel which originated in Poland. Both solid fuels used for this study are representative fuels used for heating and cooking in many households in Europe and around the world.

Domestic bottom ashes were obtained in a similar way to wood and coal bottom ashes but from a stove in a typical household in Leeds, UK. The stove used here was a type approved by DEFRA (UK's Department for Environment, Food and Rural Affairs) for use in UK smoke control areas for the purpose of household heating - hence, typical of modern domestic stoves with similar standard as the one mentioned earlier. The materials burned to obtain the domestic ash were unspecified soft and hard woods, with a few pieces of newsprint sheet used to ignite the solid fuel. Before the fire was set up, previous debris from the stove was cleaned out from the fireplace to avoid cross-contamination by previous ashes.
Coal fly ash (hereafter referred to as CFA) used in this study was fly ash released during coal combustion process in a typical large coal-fired power plant. The CFA sample used here was collected from an electrostatic precipitator, which is used to trap these particles to avoid their direct emission into the atmosphere. It should be pointed out that fly ash can escape into the atmosphere if not effectively trapped or if inefficient handling methods are applied during its transport, disposal and storage, as discussed in Sect. 1 (Buhre et al., 2005).

\section{Preparation of ash suspension and freezing experiments}

Suspensions containing CFA, wood, domestic and coal bottom ashes were prepared by suspending a known mass of a specific combustion ash in a known mass of ultra-pure water (18.2 $\mathrm{M} \Omega$ cm resistivity, TOC $<10 \mathrm{ppb}$ ) obtained from MilliQ Integral System (Millipore Water Purifier, USA). The ash particle concentration was varied and the concentrations corresponding to specific experiments are indicated in the respective figures. Also, the ash samples that were used in the preparation of the suspensions were sieved beforehand. The suspension was placed in an ultra-sonic bath (Fisherbrand FB 15050 (S30)) for about $10 \mathrm{~min}$ and then stirred continuously for $\sim 24 \mathrm{~h}$ to break down ash aggregates before carrying out freezing experiments.

We used two distinct experimental systems for the freezing experiments: the micro-litre Nucleation by Immersed Particles Instrument ( $\mu \mathrm{L}-\mathrm{NIPI})$ and its nano-litre version $(\mathrm{nL}-$ NIPI). Both $\mu$ L-NIPI and nL-NIPI are drop freezing experimental set-ups and have been described and used previously (Murray et al., 2010a; Broadley et al., 2012; Atkinson et al., 2013; O'Sullivan et al., 2014, 2015; Murray et al., 2011; Whale et al., 2014). Here, only a brief description of the procedure is presented: for experiments with nL-NIPI, ashcontaining droplets were obtained by nebulizing the ash suspension onto a hydrophobic glass slide (12 mm, HR3-277, Hampton Research, USA), and placed on a cold stage. The stage was cooled with liquid nitrogen while the freezing temperatures, video and corresponding times were recorded using a LabVIEW programme. Later, the video of the freezing droplets was analysed manually to yield the freezing temperature and size of each droplet.

For experiments with $\mu \mathrm{L}-\mathrm{NIPI}$, the droplets $(1.00 \pm 0.025 \mu \mathrm{L})$ were directly placed onto a hydrophobic glass slide (22 mm diameter) using a Picus BIOHIT electronic pipette (Sartorius Ltd, UK). The number of droplets placed on each hydrophobic glass slide in each experiment varied between 45 and 65 droplets. The glass slide was placed on a cold plate that was cooled by a Stirling cryocooler (Grant-Asymptote EF600). Temperature uncertainty for $\mu \mathrm{L}$-NIPI and nL-NIPI cold-stages are reported as \pm 0.4 and $\pm 0.2^{\circ} \mathrm{C}$, respectively (O'Sullivan et al., 2014; Atkinson 
Table 1. Specific surface areas (SSA) of combustion ashes as measured by BET nitrogen gas adsorption method. All coal fly ash (CFA), wood, domestic and coal bottom ashes were sieved to $\leq 40 \mu \mathrm{m}$ before the measurement except CFA (bulk). CFA (bulk) denotes a raw CFA sample as obtained from an electrostatic precipitator of a coal-fired power plant. All data reported here were measured from a five-point adsorption isotherm with correlation coefficient of $\geq 0.9975$. The uncertainties in the measurements are indicated on a separate column.

\begin{tabular}{lrr}
\hline Samples & $\begin{array}{r}\text { BET } \\
\left(\mathrm{m}^{2} \mathrm{~g}^{-1}\right)\end{array}$ & $\begin{array}{r}\text { Uncertainty } \\
\left(\mathrm{m}^{2} \mathrm{~g}^{-1}\right)\end{array}$ \\
\hline Coal fly ash (bulk) & 1.85 & 0.04 \\
Coal fly ash (sieved to $\leq 40 \mu \mathrm{m})$ & 2.54 & 0.04 \\
Wood ash & 6.98 & 0.30 \\
Domestic ash & 3.87 & 0.20 \\
Coal ash & 8.86 & 0.38 \\
\hline
\end{tabular}

et al., 2013; Whale et al., 2014). All results obtained from these set-ups are presented and discussed in Sect. 5.

\section{Characterization of combustion ash samples}

To ascertain the compositions of the combustion ashes, we employed a range of techniques to characterize the physical and the chemical properties of the ash samples. We measured their morphologies, surface areas, particle size distributions and mineralogy, as reported in the following sections.

\subsection{Surface areas and morphology of ash particles}

The ash particles were first size-segregated to $\leq 40 \mu \mathrm{m}$ diameter by using test sieves and a sieve shaker (Endecotts M100, UK; ISO 9001 certified). Four $100 \mathrm{~mm}$ diameter test sieves, with mesh sizes of $71,63,55$ and $50 \mu \mathrm{m}$ were stacked above the $40 \mu \mathrm{m}$ test sieve. The bottom ash particles passed through the $40 \mu \mathrm{m}$ test sieve with ease indicating that at least two dimensions of the particles were smaller than $40 \mu \mathrm{m}$ and the third could conceivably be larger. A fraction of the CFA particles were larger than $40 \mu \mathrm{m}$ and did not pass through the sieve. The sieved ash samples were then used for all characterization processes reported here.

The specific surface areas (SSAs) obtained from BET measurements of CFA and the bottom ashes are shown in Table 1. The SSAs of the ashes were measured following a standard Brunauer-Emmet-Teller (BET) nitrogen gas adsorption method (Gregg and Sing, 1982). We used an accelerated surface area and porosimetry system (Micromeritics ASAP 2020 Analyser, UK) for the measurements. Ash samples were degassed at about $120^{\circ} \mathrm{C}$ for $3 \mathrm{~h}$ prior to BET analyses.

Generally, the bottom ashes showed larger SSAs compared to CFA, with coal bottom ash particles having the largest SSA $\left(8.86 \mathrm{~m}^{2} \mathrm{~g}^{-1}\right)$. The observed variation in SSAs
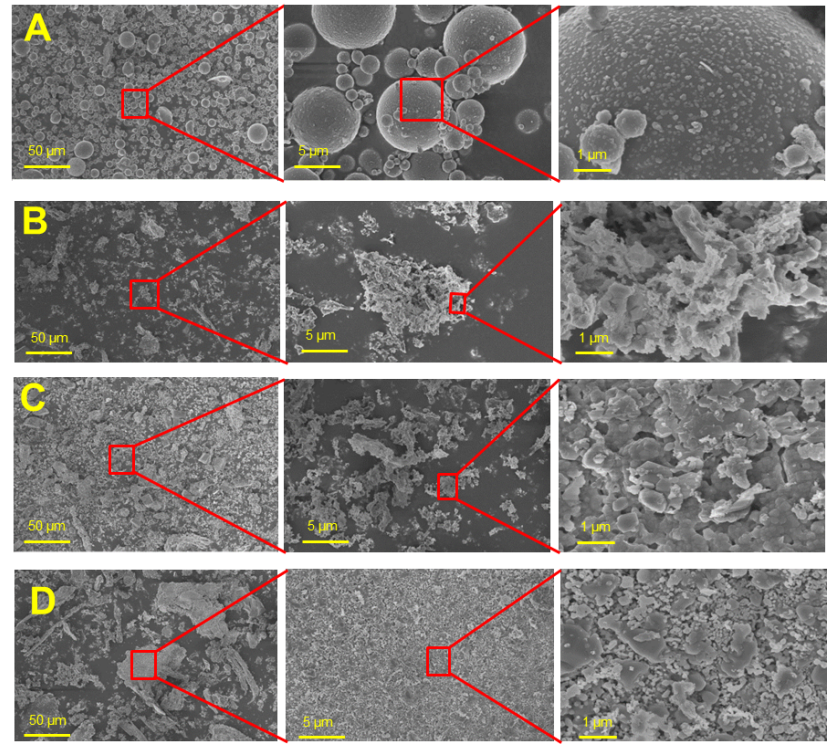

Figure 2. Scanning electron microscopy (SEM) images of CFA (a), wood bottom ash (b), domestic bottom ash (c), and coal bottom ash (d) that were used for this ice nucleation study. All ash particles were sieved to $\leq 40 \mu \mathrm{m}$ before the SEM images were taken. From left to right, the red boxes and their handles show different magnifications as presented with the scales on each SEM image panel.

of the fly ash and that of bottom ashes are related to their different morphologies which are due to different mechanisms by which the two ash types were generated (Buhre et al., 2005; Fenelonov et al., 2010).

The morphology of the combustion ash particles was also explored to see how this may influence their ice nucleation activities. A field emission gun (FEG - LEO 1530) scanning electron microscopy (SEM) instrument was used to investigate the surface properties of the ash particles; we looked at the surface morphology and the shapes of the ash particles. The SEM images of the ashes are shown in Fig. 2. From all the ashes investigated, only CFA showed spherical particles (Fig. 2a), similar to those in previous studies (Del Monte and Sabbioni, 1984; Nyambura et al., 2011; Flanders, 1999; Li and Shao, 2009); while the other ash samples had irregular shapes and tended to form aggregates.

The spherical shape of CFA particles is attributed to the formation mechanism of these particles as discussed previously by Fenelonov et al. (2010). Some CFA particles formed hollow spheres, which are referred to as cenospheres, and some of these hollow particles may be filled up by smallersized CFA particles and are referred to as plerospheres. High combustion temperatures and expansion of gas pockets are required for the formation of cenospheres, which is consistent with the production of this fly ash in a commercial power station. The average diameter of CFA particles based on the SEM images was measured by using Image $\mathbf{J}^{\circledR}$ software as $\sim 5 \mu \mathrm{m}$. 
Wood bottom ash particles showed irregular shapes and aggregated particles as shown in Fig. 2b, but generally smaller in size compared to the CFA particles. Domestic bottom ash particles were highly agglomerated and asymmetrical shaped as shown in Fig. 2c - again, smaller than CFA particles but within the same size range as wood bottom ash particles (Fig. 2b). Domestic and wood bottom ashes were generated in similar combustion conditions and a similar fuel source; hence, they present similar particle morphologies. The SEM images of coal bottom ash particles (Fig. 2d) show that they were highly agglomerated and comprised smaller particles than CFA in spite of having a similar fuel source (coal), although formed under different combustion conditions. Owing to the irregular shapes of all the bottom ash samples, it was not possible to estimate mean particle sizes from the SEM images.

\subsection{Size distribution of combustion ash particles}

We measured the particle size distribution for the combustion ash particles with a Malvern Mastersizer 2000E laser diffraction instrument that uses Mie theory to estimate the equivalent volume of the particles (Malvern, 2012; De Boer et al., 2002). A refractive index of 1.62 and absorption value of 1.0 was used for CFA and coal bottom ash based on suggestions by Jewell and Rathbone (2009). For wood and domestic bottom ashes, we used a refractive index of 1.65 and an absorption value of 0.1 because of their higher calcite or $\mathrm{CaO}$ content (>10\%, see Table 2) (Jewell and Rathbone, 2009). The results in Fig. 3 are volume fraction size distributions for ash suspensions agitated and stirred in the same way as for the ice nucleation experiments. From these measurements, we report an average volume equivalent particle diameter of $\sim 10 \mu \mathrm{m}$ for CFA while that of the bottom ashes is $\sim 8 \mu \mathrm{m}$ (Fig. 3). The SEM images for CFA particles were consistent with the size distribution determined by laser diffraction. The SEM images for CFA particles showed a slightly smaller average diameter of $\sim 5 \mu \mathrm{m}$, but only relatively few particles were imaged in the SEM compared to the laser diffraction method, which looked at a large volume of the material.

\subsection{Mineralogical analyses and elemental compositions of combustion ashes}

The mineral compositions of the combustion ashes were analysed with an X-ray powder diffractometer (Bruker D8) and mineralogical composition determined using Rietveld refinement; the results are reported in Table 2. The X-ray diffraction patterns and Rietveld fits are given in the Supplement. The results showed variability in the mineral compositions of each ash type, but the proportions of major minerals such as quartz, calcite, haematite and magnetite were similar to biomass ash (Vassilev et al., 2013a, b; Misra et al., 1993). Quartz and haematite are also present in natural desert dust samples, but the ash samples used here are dis-

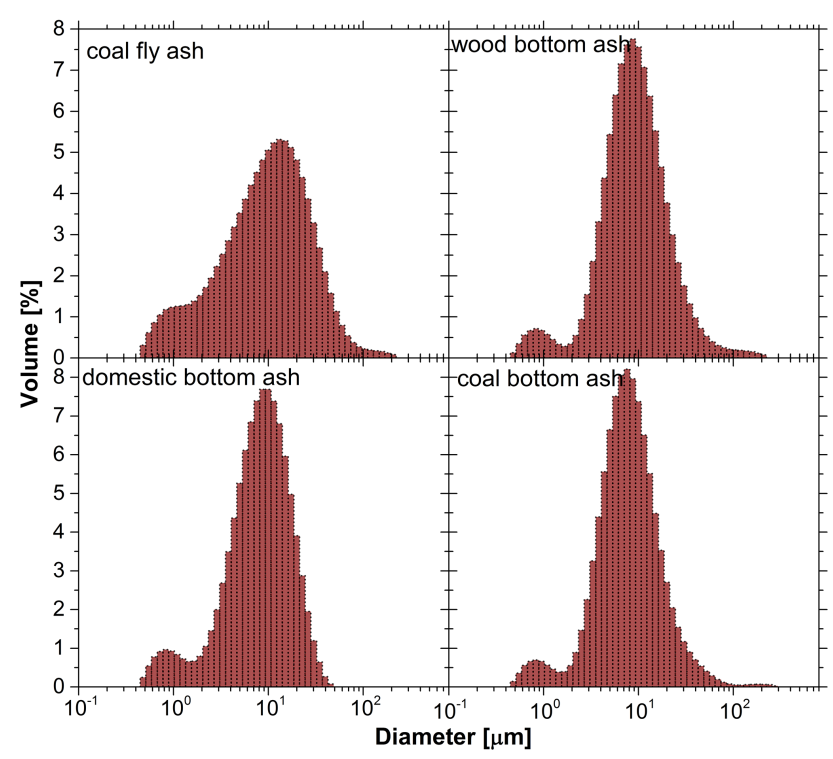

Figure 3. Particle size distribution of suspended combustion ash particles - coal fly ash (CFA), wood, domestic, and coal bottom ashes. The size distribution were measured after the ash suspensions were pulsated in an ultra-sonic bath for about $10 \mathrm{~min}$ and stirred for $\sim 24 \mathrm{~h}$ before the laser diffraction measurement. Each plot of the size distribution shown for each ash sample is an average of three repeated measurements $(\sigma<0.01)$.

tinct from typical desert dusts in that they do not contain measurable amounts of clay and feldspar minerals. Another important distinction from desert dusts is that combustion ash samples contain 29 to $85 \%$ amorphous materials. Mullite $\left(\mathrm{Al}_{6} \mathrm{Si}_{2} \mathrm{O}_{13}\right)$ was detected in CFA but not in the bottom ashes studied, and is formed at the high combustion temperature of $\sim 1100^{\circ} \mathrm{C}$ relevant for CFA production (Liu et al., 1994; Li and Thomson, 1990).

Focusing on the CFA used in this study, we found that its mineral composition (Table 2) was similar to the mineralogy of CFAs from different sources and locations. For example, the X-ray diffraction (XRD) mineralogy for CFA in this study was found to be similar to CFA obtained from Sasol in South Africa (Nyambura et al., 2011). Also, a study of CFAs from five separate power plants in the USA showed similar mineral compositions (ACAA, 2012). However, the amorphous content of the South African CFA (65\%) was different from the bulk sample used here $(81 \%)$. Previously, it has been reported that over $90 \%$ of CFA contain silicon-, aluminium-, calcium- and iron-based minerals (EPRI, 2010); this is consistent with the XRD and energy-dispersive X-ray spectroscopy (EDX) results obtained for our CFA. In general, fly ash from large power plants are not strongly varied and our results for its ice-nucleating abilities are therefore representative of coal power stations around the globe.

EDX analyses were carried out to study the elemental composition of individual ash particles. This was achieved 
Table 2. Mineral compositions (\%) of CFA, wood, domestic and coal bottom ashes as measured from an X-ray powder diffractometer. All ash samples were sieved to $\leq 40 \mu \mathrm{m}$ except for CFA (bulk), which mineral composition analysis was performed on the raw sample as obtained from the coal-fired power plant. A greater part of the combustion ash samples consisted of amorphous materials. The mineral composition is reported in percentages of the total volume of the sample used. ND represents mineral concentrations that were beyond the detectable limits.

\begin{tabular}{|c|c|c|c|c|c|c|}
\hline \multirow[b]{2}{*}{ Minerals } & \multirow[b]{2}{*}{ Chemical formulae } & \multicolumn{5}{|c|}{$\begin{array}{l}\text { Combustion ash samples and their } \\
\text { mineral compositions }(\%)\end{array}$} \\
\hline & & $\begin{array}{r}\text { CFA } \\
\text { (bulk) }\end{array}$ & $\begin{array}{r}\text { CFA } \\
(\leq 40 \mu \mathrm{m})\end{array}$ & $\begin{array}{r}\text { Wood } \\
\text { ash }\end{array}$ & $\begin{array}{r}\text { Domestic } \\
\text { ash }\end{array}$ & $\begin{array}{r}\text { Coal } \\
\text { ash }\end{array}$ \\
\hline Quartz & $\mathrm{SiO}_{2}$ & 7.1 & 5.7 & 0.7 & 0.7 & 0.3 \\
\hline Mullite & $\mathrm{Al}_{6} \mathrm{Si}_{2} \mathrm{O}_{13}$ & 9.8 & 8.1 & ND & ND & ND \\
\hline Calcite & $\mathrm{CaCO}_{3}$ & ND & ND & 47.4 & 4.3 & 55.1 \\
\hline Haematite & $\mathrm{Fe}_{2} \mathrm{O}_{3}, \alpha-\mathrm{Fe}_{2} \mathrm{O}_{3}$ & 0.5 & 0.5 & 1.1 & 3.1 & 0.3 \\
\hline Magnetite & $\mathrm{Fe}^{2+} / \mathrm{Fe}_{2}^{3+} \mathrm{O}_{4}$ & 1.2 & 1.1 & ND & 2.6 & 0.3 \\
\hline Fairchildite & $\mathrm{K}_{2} \mathrm{Ca}\left(\mathrm{CO}_{3}\right)_{2}$ & ND & ND & 15.4 & ND & 12.1 \\
\hline Portlandite & $\mathrm{Ca}(\mathrm{OH})_{2}$ & ND & ND & 6.4 & ND & ND \\
\hline Periclase & $\mathrm{MgO}$ & ND & ND & ND & 7.7 & ND \\
\hline Anhydrite & $\mathrm{CaSO}_{4}$ & ND & ND & ND & 7.7 & ND \\
\hline Goethite & $\mathrm{Fe}^{3+} \mathrm{O}(\mathrm{OH})$ & ND & ND & ND & 1.7 & ND \\
\hline Muscovite $1 \mathrm{M}$ & $\mathrm{KAl}_{2}\left(\mathrm{AlSi}_{3} \mathrm{O}_{10}\right)(\mathrm{OH})_{2}$ & ND & ND & ND & 3.8 & ND \\
\hline Lime & $\mathrm{CaO}$ & ND & ND & ND & ND & 0.9 \\
\hline Amorphous components & - & 81.3 & 84.6 & 29 & 68.4 & 31 \\
\hline
\end{tabular}

using an EDX instrument (XMax $80 \mathrm{~mm}^{2}$ by Oxford Instruments, UK), which was coupled to the SEM instrument. The key elements found in the CFA EDX spectra are shown in Fig. 4. Based on the locations scanned, principal elements found were $\mathrm{Al}, \mathrm{Si}, \mathrm{Fe}, \mathrm{O}$, and $\mathrm{C}$. These elements are the major components of the minerals identified by the XRD. This result agrees with literature EDX spectra of ultra-fine ash particles, which is reported to comprise high levels of $\mathrm{Ca}, \mathrm{Si}$, and $\mathrm{Fe}$ (Chen et al., 2005). Although carbon (C) showed a high count in the EDX spectra, it is not part of the major minerals listed; it could be a component of CFA's amorphous composition. The elemental composition of coal bottom ash was similar to that of CFA but with a higher count for Ca (EDX spectra for the bottom ashes are shown in the Supplement.).

The EDX spectra for wood and domestic bottom ashes identified the elements $\mathrm{C}, \mathrm{O}, \mathrm{Ca}, \mathrm{Si}, \mathrm{Mn}, \mathrm{Fe}, \mathrm{Mg}, \mathrm{S}, \mathrm{Na}$ and $\mathrm{K}$. High counts were observed for $\mathrm{C}, \mathrm{O}, \mathrm{Mg}, \mathrm{K}$ and $\mathrm{Ca}$. Potassium $(\mathrm{K})$ is frequently found in combustion particles coming from wood fuel (Jenkins et al., 1998). From the XRD, the mineralogy of both wood and domestic bottom ashes shows that $\mathrm{CaCO}_{3}, \mathrm{~K}_{2} \mathrm{Ca}\left(\mathrm{CO}_{3}\right)_{2}$ and $\mathrm{CaSO}_{4}$ are the major components. Therefore, high elemental contents of $\mathrm{Ca}$ and $\mathrm{O}$ are from the calcite and anhydrite (the anhydrous form of gypsum) minerals found in them. The amount of $\mathrm{SiO}_{2}$ present was relatively small, but the signal from $\mathrm{Si}$ was higher in some of the EDX scans while, in other scans, it was substantially lower. Also, it is possible that the location (or particle) where the EDX scanned did not contain quartz in a significant proportion. Overall, the elements identified were consistent with the mineralogy established by the XRD.

\section{Results and discussion - ice nucleation by combustion ash samples}

In this section, we present and discuss the results obtained from the freezing experiments on combustion ash particles.

\subsection{Droplet freezing results}

The results from the $\mu$ L-NIPI freezing experiments with ash are shown in Fig. 5 and are compared with the average of 23 freezing experiments with ultra-pure water. In all cases, droplets containing combustion ash samples froze at higher temperatures than ultra-pure water indicating that combustion ashes are capable of nucleating ice heterogeneously in the immersion mode.

The results of the nL-NIPI droplet freezing experiments are shown in Fig. 6. In these experiments the majority of the nano-litre-volume droplets of pure water containing no ash froze below $-36^{\circ} \mathrm{C}$, consistent with homogeneous nucleation reported by Murray et al. (2010a) and Riechers et al. (2013). This allows us to study ice nucleation by combustion ashes to lower temperatures than possible in the microlitre experiments. Inclusion of ash in these droplets causes them to freeze at higher temperatures than in the pure water experiments, which indicates that the ash particles also nucleate ice in a temperature range not accessible to the $\mu \mathrm{L}$ NIPI experiment. The heterogeneous freezing temperatures for the nL-NIPI are lower than those for the $\mu \mathrm{L}-\mathrm{NIPI}$, because nano-litre volume droplets with the same concentration of ash contain less ash, and hence have a lower probability of freezing at a given temperature. 

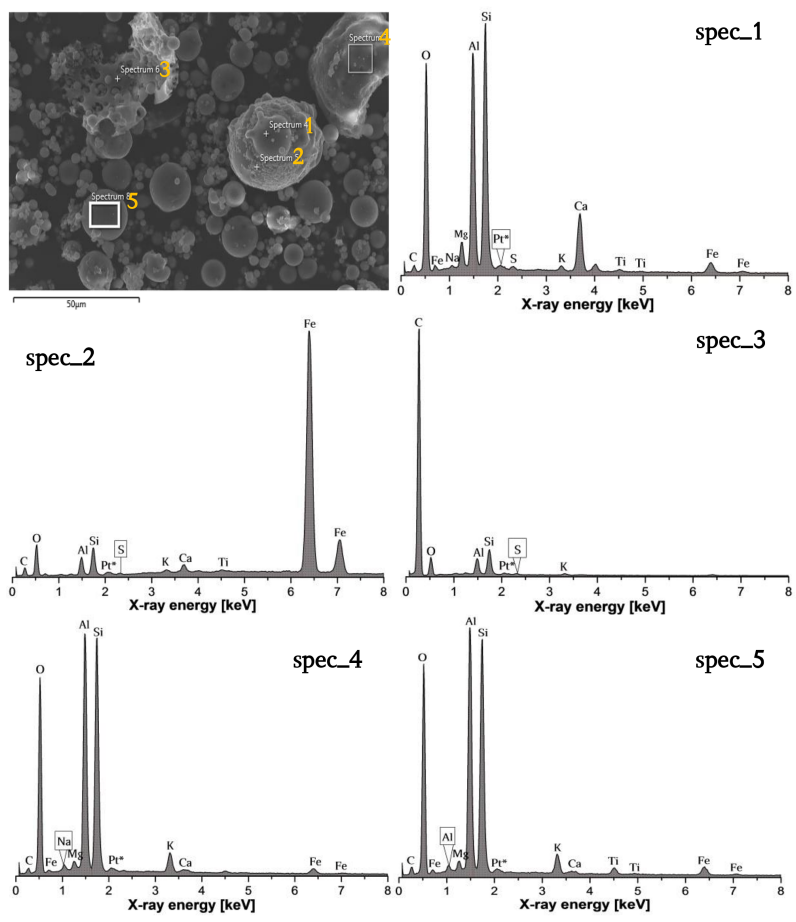

Figure 4. Elemental composition of CFA measured by energy dispersive X-ray spectroscopy (EDX) that was coupled to a scanning electron microscope (SEM). Platinum / palladium ( $\mathrm{Pt} / \mathrm{Pd}$ ) mixture was used to coat the samples before SEM/EDX spectra were taken; hence, it is asterisked on the spectra. These spectra were background corrected before making this plot. The ordinate (which is not shown) is intensity, in counts per second per energy unit $\left(\mathrm{cps} \mathrm{eV}^{-1}\right)$. The spectra labels (spec_1, spec_2, $\ldots$, spec_ $n$ ) on the SEM images are the locations from which the EDX scanned. EDX spectra for the bottom ash samples are given in the Supplement.

In these experiments, droplets were generated by nebulizing $0.1 \mathrm{wt} \%$ aqueous suspensions of ash and the nano-litre droplets were collected on a glass slide. As a result there was a very broad droplet size distribution (20-450 $\mu \mathrm{m}$, diameter), unlike in the $\mu \mathrm{L}$-NIPI experiments where the droplets were of almost identical size. Importantly, there were also significant differences in droplet size distribution between experiments. Hence, the fraction frozen plots for each individual experiment in Fig. 6 are for a different droplet size distribution and cannot be directly compared. When the distribution was made up of smaller droplets, and therefore less surface area per droplet, the freezing temperatures are lower and vice versa. To quantitatively compare data from different runs on the nL-NIPI and also compare data from the nL-NIPI and $\mu \mathrm{L}$-NIPI experiments we need to normalize the probability of nucleation to the surface area per droplet.

\subsection{The ice nucleation efficiency of combustion ashes}

In order to describe the ice-nucleating abilities of the different combustion ashes investigated, a singular model was adopted, which describes the cumulative number of active sites $\left(n_{\mathrm{s}}\right)$ which nucleate ice on cooling to a characteristic temperature $(T)$ expressed per unit surface area of combustion ash. This model has been used in many ice nucleation studies to describe the ice-nucleating efficiencies of particles, and detailed description of the model has also been given in Vali (1971, 2014), Connolly et al. (2009), Broadley et al. (2012), Murray et al. (2011, 2012), Niedermeier et al. (2010), Hoose and Möhler (2012), Atkinson et al. (2013) and O'Sullivan et al. (2014). $n_{\mathrm{s}}$ is defined as

$n_{\mathrm{S}}(T)=-\ln \left(1-f_{\text {ice }}(T)\right) A^{-1}$,

where $f_{\text {ice }}$ is the cumulative fraction of frozen droplets, which we implicitly assume is equal to the probability of a droplet being frozen at $T$, and $A$ is the surface area of the particles per droplet. The value of $A$ is determined from the SSA reported in Table 1 together with the mass fraction of the original suspension and the droplet volume.

For the $\mu \mathrm{L}$-NIPI some of the fraction frozen curves for droplets containing ash overlap in temperature range with the background freezing in pure water. In the past, $\mu \mathrm{L}$-NIPI results have only been quoted above a threshold temperature above which the background is negligible (Atkinson et al., 2013; O'Sullivan et al., 2014; Whale et al., 2014). Here we use a method to subtract the background INP concentration and determine $n_{\mathrm{s}}$ to lower temperatures. In this method, the cumulative INP concentration (INP per unit volume) for the background $\left(K_{\text {bgd }}\right)$ is subtracted from the cumulative INP concentration for the ash containing samples $\left(K_{\text {tot }}\right)$ :

$K_{\text {het }}=K_{\text {tot }}-K_{\text {bgd }}$.

Here the $K_{\text {het }}$ is the cumulative INP concentration due to the heterogeneous freezing by the ash samples. $K_{\text {bgd }}$ is obtained from the fit to the experimental data of ultra-pure water given as

$K_{\mathrm{bgd}}=\exp (m T+d)$

where $m(-0.44 \pm 0.01)$ and $d(-5.08 \pm 0.24)$ are the gradient and intercept of the fit, respectively. $K_{\text {het }}$ is then used to determine $n_{\mathrm{s}}$ as shown in Eq. (4). The determination of $K$ and its relationship with $n_{\mathrm{S}}$ is set out by Murray et al. (2012) and Vali (2014):

$n_{\mathrm{S}}(T)=\left[-\ln \left(1-f_{\mathrm{tot}}\right) V^{-1}-\exp (m T+d)\right] V A^{-1}$

where $V$ is the average volume of a droplet $\left(\mathrm{cm}^{3}\right)$ and $A$ is the surface area of ash particles per droplet. Uncertainties in $K_{\mathrm{bgd}}$, droplet volume and specific surface area are propagated to estimate the uncertainty in $n_{\mathrm{s}}$. A comparable methodology was recently employed by Hader et al. (2014) and O'Sullivan et al. (2015) to correct for background freezing in similar experiments for heterogeneous freezing by pollen and nanoscale biological fragments, respectively. 


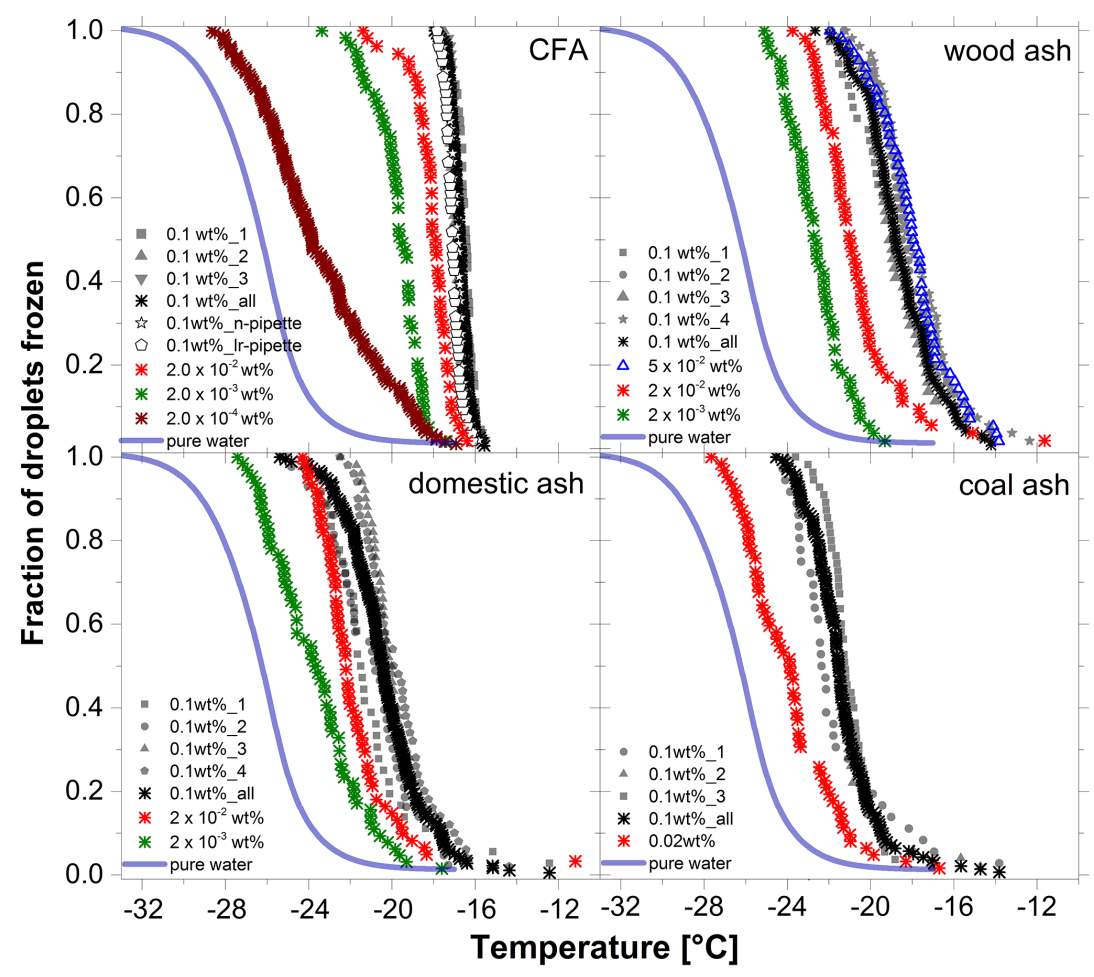

Figure 5. Fraction of droplets frozen $\left(f_{\text {ice }}\right)$ from freezing experiments in the $\mu$ L-NIPI. Each panel shows freezing curves of droplets containing known concentrations (wt \%) of CFA, wood, domestic and coal bottom ashes. In all the panels, a fit to the background freezing (blue line) of ultra-pure water $(18.2 \mathrm{M} \Omega \mathrm{cm}$ resistivity) is plotted. All plots labelled as " $0.1 \mathrm{wt} \%$ all" on every panel are cumulative fractions frozen obtained from many repeat experiments. n-pipette represents normal pipette tips and lr-pipette is for low-retention pipette tips. All experiments shown in this figure were performed with the n-pipette except indicated. The temperature uncertainty for $\mu \mathrm{L}-\mathrm{NIPI}$ is quoted as $\pm 0.4 \mathrm{~K}$ for all measurements and it is not plotted with the data points for the purpose of clarity.

For the nL-NIPI experimental results, the determination of $n_{\mathrm{s}}$ needed to take into account the broad size distribution of the droplets $(20-450 \mu \mathrm{m}$ diameters). In the past, we have used a method where we bin droplets into narrow size ranges as described above and then apply Eq. (1) using the average surface area per droplet (Murray et al., 2011). However, this method relies on the assumption that we can take an average surface area per droplet in each bin. This is an appropriate assumption only when the size bin is narrow and was found to be justified in previous work - e.g. Murray et al. (2011) and Broadley et al. (2012). In the case of the nL-NIPI experiments presented here the size distribution is very broad and it is not possible to bin the limited number of droplets in sufficiently small size bins. This leads to an underprediction at lower temperatures.

Instead, we have used a moving average method similar to that used by Vali (1971). In this analysis the average surface area per droplet is defined as

$A=\frac{S_{\mathrm{liq}, T}}{n_{\mathrm{liq}, T}}$,

where $S_{\text {liq, } T}$ is the total surface area of the ash in liquid (unfrozen) droplets at $T$, and $n_{\mathrm{liq}, T}$ is the number of liq- uid droplets remaining at $T$. Hence, $A$ generally decreases through an experiment as the largest droplets tend to freeze first and therefore provides a better approximation of $n_{\mathrm{s}}$ than the standard method. $A$ is used to determine differential nucleus spectrum $k(T)$ :

$k(T)=-\ln \left(1-\frac{n_{i}}{n_{\mathrm{liq}, T}}\right)(A . \Delta T)^{-1}$,

where $n_{i}$ is the total number of frozen droplets in the temperature step $(\mathrm{d} T)$. This can be used to derive the cumulative value, $n_{\mathrm{s}}$ (Vali, 1971):

$n_{\mathrm{s}}=-\int_{0}^{T} k(T) \mathrm{d} T$.

Values of $n_{\mathrm{s}}$ for each combustion ash sample from both $\mu \mathrm{L}-$ and nL-NIPI experiments are presented in Fig. 7. The $n_{\mathrm{s}}$ distribution of results from both $\mu \mathrm{L}$ - and nL-NIPI experiments showed good agreement even though the surface area per droplet varied by 6 orders of magnitude. The agreement between data from experiments with vastly different droplet volumes and therefore vastly different surface areas 


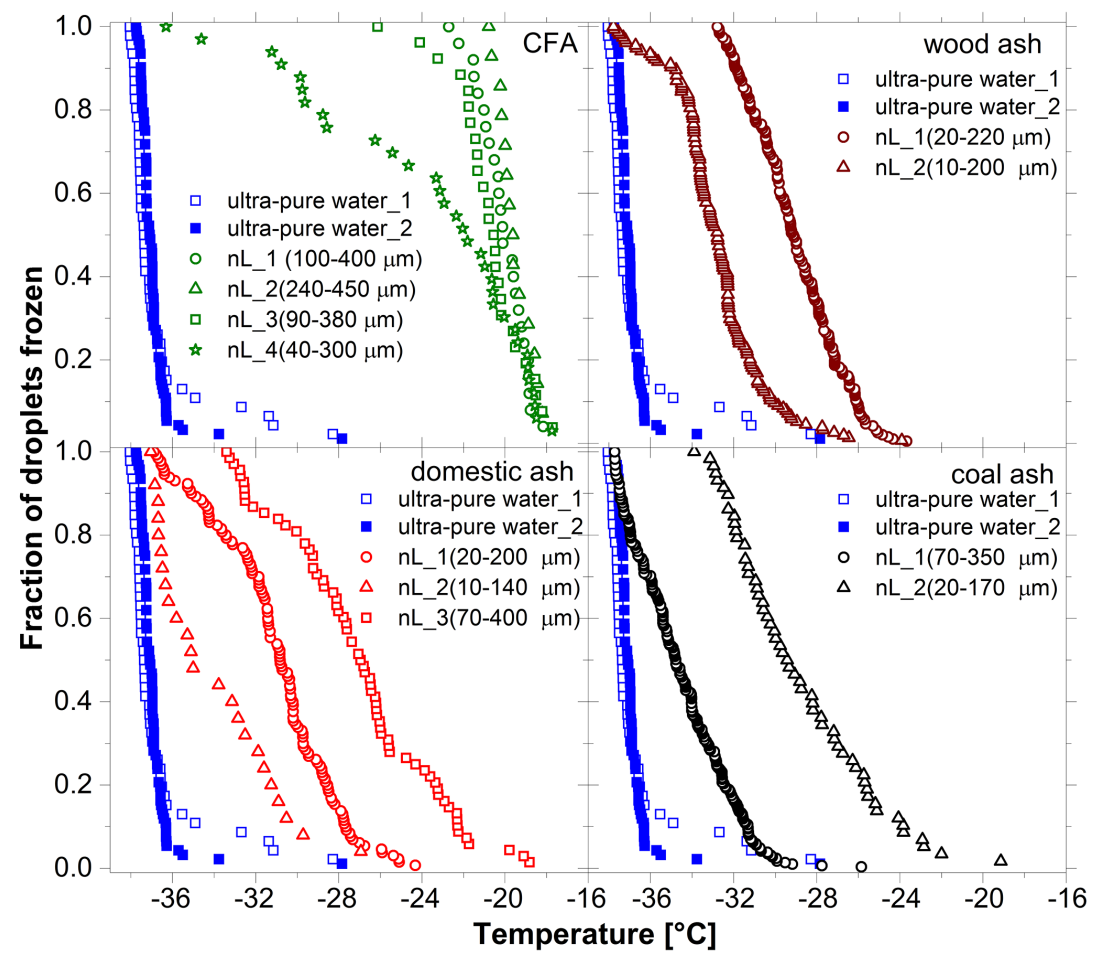

Figure 6. Fraction of droplets frozen $\left(f_{\text {ice }}\right)$ from freezing experiment in the nL-NIPI. Each panel shows freezing curves of droplets containing $0.1 \mathrm{wt} \%$ of CFA, wood, domestic or coal bottom ashes. The size range of the droplets varied from $\sim 20$ to $450 \mu \mathrm{m}$ diameter. We give the range of the droplet diameter, but note that this is a rough guide to the size distribution since the distributions were commonly not log-normal. Most of the experiments in this figure were for droplets in the nano-litre (nL) volume range. For all panels, the royal blue squares (filled and unfilled) represent the freezing curve of ultra-pure water $(18.2 \mathrm{M} \Omega \mathrm{cm}$ resistivity) on the same instrumental set-up with droplets ranging from 30 to $400 \mu \mathrm{m}$ diameter for both runs. Uncertainty in the temperature measurements is quoted as $\pm 0.2 \mathrm{~K}$.

per droplet is consistent with the probability of nucleation scaling with surface area.

In the determination of $n_{\mathrm{s}}$ from nL-NIPI results we assumed that the background INP concentrations were negligible. In general, this appears to be a reasonable approximation, but it is possible that for runs employing the largest droplets $(>100 \mu \mathrm{m})$ there may have been a significant number of background INPs present in the droplets. Accordingly, this could lead to an overestimation for the highesttemperature nL-NIPI $n_{\mathrm{S}}$ values when compared to the equivalent $\mu \mathrm{L}-$ NIPI $n_{\mathrm{s}}$ values. Note that some pure water droplets freeze above $-36^{\circ} \mathrm{C}$ (Fig. 6). Even with this potential contribution of background INP in some nL-NIPI experiments, the agreement between the various experiments shown in Fig. 7 is reasonable.

Inspection of the various plots in Fig. 7 reveals a striking difference in temperature dependence of $n_{\mathrm{s}}$ between the CFA and the bottom ash samples. While CFA is well described by a log-exponential fit, wood and coal bottom ashes were well described by a log-linear relationship and domestic ash was better fitted by a log-polynomial fit. The fitted parameterizations for each data set are listed in Table 3. The shape of the CFA $n_{\mathrm{s}}$ curve is reminiscent of bacterial or fungal INP in which there is an onset-like behaviour where the number of active sites increases rapidly with temperature, followed by a much shallower increase in active sites at lower temperature. The steep increase in $n_{\mathrm{s}}$ around $-17^{\circ} \mathrm{C}$ in CFA shows that the sites active around this temperature are less diverse than those in the bottom ash samples. In contrast, the bottom ash samples have measurable $n_{\mathrm{s}}$ to temperatures well above $-17^{\circ} \mathrm{C}$.

In Fig. 8, we compare the $n_{\mathrm{s}}(T)$ of the four ash samples (mineral dust $n_{\mathrm{s}}$ values are also included in this plot, but are discussed in Sect. 5.3). Inspection of Fig. 8 shows that CFA is more efficient at nucleating ice between about -17 and $-27^{\circ} \mathrm{C}$ than the bottom ashes, but its activity falls away very rapidly above $-17^{\circ} \mathrm{C}$. The bottom ash samples are more similar to one another, but there is a trend with the coal ash being least active and the wood ash being most active between $\sim-12^{\circ} \mathrm{C}$ and the homogeneous limit. These differences must in some way be related to the fuel, combustion temperature, ash composition and ash morphology. In terms of morphology and generation conditions, CFA is very different to the bottom ashes. As shown earlier (Fig. 2), CFA was made up of spherical particles whereas the bottom ashes were irregular-shaped particles. Moreover, CFA 


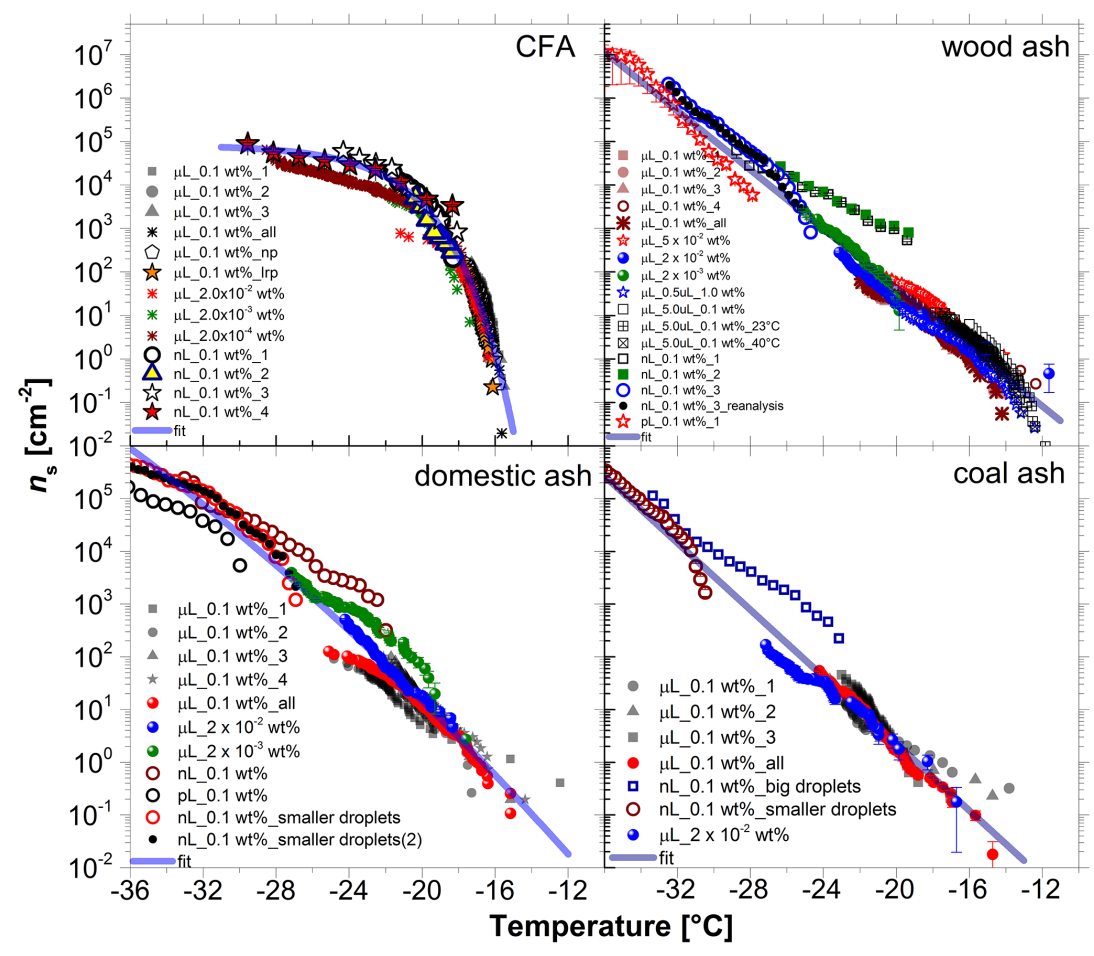

Figure 7. Ice nucleation active sites $\left(n_{\mathrm{S}}\right)$ distribution for CFA, wood bottom ash, domestic bottom ash, and coal bottom ash particles, obtained from freezing experiments in $\mu \mathrm{L}$ - and nL-NIPI. Each panel represents the cumulative number of nucleation active sites $\left(n_{\mathrm{S}}\right)$ on the ash particles calculated from the ice nucleation singular model and it covers all the temperature range explored during the freezing experiments. For the $\mu \mathrm{L}$-NIPI experiments, n-pipette represents normal pipette and lr-pipette is for low retention pipette - all experiments shown in this figure were performed with the $n$-pipette $(1.00 \pm 0.025 \mu \mathrm{L})$ except where indicated. On the wood bottom ash panel, the experiments indicating 23 and $40^{\circ} \mathrm{C}$ were performed to test the effect of the initial temperature of the suspensions on its freezing ability. The equations for the $n_{\mathrm{S}}$ parameterizations and their valid temperatures for each of the combustion ashes are shown in Table 3. Estimated error bars are only shown for a selection of data sets for clarity and in many of these cases the error bars are smaller than the size of the data points.

Table 3. $n_{\mathrm{s}}$ parameterizations for combustion ash samples investigated in this report. The temperature $\left({ }^{\circ} \mathrm{C}\right)$ ranges for which the fits are valid are shown for each of the ash type.

\begin{tabular}{llrl}
\hline Combustion ash type & $n_{\mathrm{S}}(T)$ fit $\left(\mathrm{cm}^{-2}\right)$ & $R^{2}$ & Valid temperature range $\left({ }^{\circ} \mathrm{C}\right)$ \\
\hline Coal fly ash (CFA) & $\exp [11.3014-1712.27 \cdot \exp (0.3153 T)]$ & 0.9390 & -15 to -31.5 \\
Wood bottom ash & $\exp [-0.7818 T-11.884]$ & 0.9469 & -11 to -36 \\
Domestic bottom ash & $\exp \left[-15.5721-1.0386 T-0.0063 T^{2}\right]$ & 0.9525 & -12 to -35 \\
Coal bottom ash & $\exp [-0.7305 T-13.802]$ & 0.9551 & -13 to -36 \\
\hline
\end{tabular}

was produced in a high-temperature combustion system, at $1500-1900^{\circ} \mathrm{C}$, in contrast to the bottom ashes which were generated at about $800^{\circ} \mathrm{C}$ (see Sect. 2.1). CFA was produced at a very high temperature in a limited oxygen condition, the bottom ashes were generated in a sufficient oxygen supply system. These combustion conditions can affect the chemistry and composition of the particles (Misra et al., 1993), and apparently also influence ice-nucleating abilities. However, the particular reason why CFA has a distinct nucleation spectrum remains a subject for further investigation.

\subsection{Comparison of ice nucleation activities of combustion ashes to INPs with varied mineralogies}

Combustion ashes have some similarities with mineral dusts from deserts in terms of their composition; hence, we have compared literature values of $n_{\mathrm{s}}$ for various mineral and desert dusts in Fig. 8. For mineral-based INPs, the observed variations in their ice nucleation activities have been linked to differences in their mineralogies (Atkinson et al., 2013; Augustin-Bauditz et al., 2014). In particular, feldspars have been identified as the most active mineral group present in typical desert dusts followed by quartz with the clays 


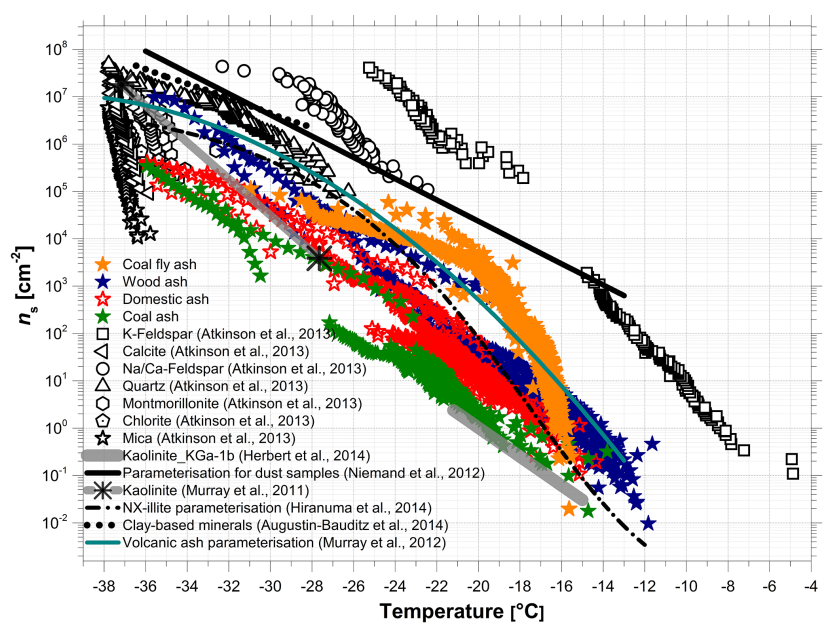

Figure 8. Comparison of ice nucleation active sites $\left(n_{\mathrm{S}}\right)$ distribution for combustion ashes and other mineral INPs such as mica, montmorillonite, chlorite, feldspar ( $\mathrm{Na} / \mathrm{Ca}$ ) (albite), calcite, quartz, Kfeldspar (microcline) taken from Atkinson et al. (2013), kaolinite (KGa-1b) from Herbert et al. (2014), and kaolinite from Murray et al. (2011). The solid black line, dotted black line, solid cyan line and the dashed-dotted black line are parameterizations for the immersion freezing of desert dusts (Niemand et al., 2012), clay-base mineral line (Augustin-Bauditz et al., 2014), volcanic ash (Murray et al., 2012) and NX-illite (Hiranuma et al., 2015), respectively. All coloured data points are for the different combustion ashes investigated in this present study. All the data shown here were derived from the BET surface area except for parameterizations for dust samples (Niemand et al., 2012) and volcanic ash (Murray et al., 2012), which were based on the geometric surface areas calculations.

only becoming similarly active at much lower temperatures (Atkinson et al., 2013).

The combustion ashes showed less activity than the feldspars reported by Atkinson et al. (2013) and the desert dust samples parameterized by Niemand et al. (2012). It was suggested by Atkinson et al. (2013) that these desert dusts also contained feldspars which determined their icenucleating activity. X-ray diffraction analyses (Table 2) showed no detectable feldspar present in the ash samples, but there was a detectable amount of quartz in all samples. In fact, the $n_{\mathrm{s}}$ values for the ashes ranges from roughly 30 to $1 \%$ of that of the available literature data for quartz at $<-26^{\circ} \mathrm{C}$. This suggests that quartz could be important in the ice-nucleating activity of combustion ashes, but further work is required to explore this hypothesis. One major difference between the ash samples and mineral dusts is that the ash samples contain a substantial proportion of amorphous material (Table 2). Amorphous solids have been shown to nucleate ice in the past (Murray et al., 2010b; Wilson et al., 2012; Baustian et al., 2013), and aluminium silicates also nucleate ice under cirrus cloud conditions (Archuleta et al., 2005), but the ice-nucleating ability of the amorphous silicates in ash at mixed-phase cloud conditions remains unknown. In general, the combustion ashes have an intermediate, but variable, icenucleating activity. They have greater or similar activity to clay minerals (illite, kaolinite, montmorillonite) and calcite, but lower activity than quartz, feldspars and desert dusts. The components and surface properties that control the ice nucleation activity of combustion ashes remains a subject for future investigation.

\section{Atmospheric implications of combustion ash particles as ice nuclei and future research}

The relative importance of some INP types relevant for mixed-phase clouds have been assessed previously by combining $n_{\mathrm{s}}$ values with atmospheric abundance to yield an estimate of the INP concentrations (Cziczo et al., 2013; Murray et al., 2012; Atkinson et al., 2013; O'Sullivan et al., 2014; Tobo et al., 2014). This sort of quantification can give an insight into the importance of INPs from different sources and potentially allows us to assess changes in INP concentrations due to human activities. Unfortunately, such an estimate is not possible for combustion ashes, because we have a very limited knowledge of the atmospheric abundance of combustion ashes. Some of the limiting factors that lead to unavailability of data are linked to a lack of airborne and ground measurements of combustion ash particles, and the difficulty in differentiating mineral dust and combustion ashes in the atmosphere. For example, in some ice crystal residue analyses natural mineral dusts, fly ashes, volcanic ashes and others are often classed into a single category (Richardson et al., 2007; Baustian et al., 2012; Kamphus et al., 2010; Friedman et al., 2013; Cziczo et al., 2004). Some studies only used dust markers to class such aerosols as mineral dust (e.g. Pratt et al., 2009) or grouped aerosol particles as simply mixed or industrial (Pratt et al., 2010). Similar comments have been made by Wang et al. (2013) about the incorrect apportionment of coal combustion particles in the atmosphere to biomass burning sources.

In this study, we have provided the first direct evidence that combustion ash particles can nucleate ice in the immersion mode. These particles may contribute to the INP budget in the atmosphere, which is needed for a complete assessment of impact of cloud adjustment due to aerosol particles. As the global energy demand increases, more fly ash may be produced. It is estimated that with the current increase in annual global consumption of coal (2-3\%), by 2030, up to 10.6 billion tonnes may be needed (Zhang et al., 2008). In addition, it is predicted that due to land use change more wildfires are likely to occur (Westerling et al., 2006) - hence, more biomass ash particles may be released into the atmosphere. We strongly suggest that it is necessary to quantify the concentration and distribution of combustion ash particles in the atmosphere and to understand their ice nucleation 
mechanisms. This will help in proper assessment of their effects on mixed-phase clouds.

\section{Conclusions and recommendations}

We investigated the ice nucleation efficiencies of combustion ashes - CFA, wood, domestic, and coal bottom ashes - in the immersion mode. From this study, we have shown that combustion ash particles nucleate ice heterogeneously in the immersion mode. We also show that there are substantial differences between ice-nucleating abilities of the ashes generated from different fuels and under different conditions. Ashes are composed of silicates and might therefore be expected to have some similarities in their ice-nucleating ability to mineral dusts, but the nucleating efficiency $\left(n_{\mathrm{s}}\right)$ of the ashes is lower than that of desert dusts reported in the literature. This is probably because the ashes do not contain the highly ice active feldspars, which are present in desert dusts. However, the ice nucleation activities of combustion ashes may be influenced by the presence of quartz, but this suggestion needs further investigation.

At present it is not possible to assess the potential contribution of ashes to the INP loading of the Earth's atmosphere due to a lack of data on their atmospheric abundance. There is a lack of information on the abundance of combustion ashes in the atmosphere, in part, because these ashes are difficult to distinguish from mineral dusts and therefore tend to be counted together with mineral dust particles. There is only one study we are aware of where the contribution of fly ash to ice crystal residues was estimated (DeMott et al., 2003). This study was for cirrus cloud conditions rather than lower-altitude mixed-phase clouds, and hence may not be directly relevant, but nevertheless illustrates the potential importance of combustion ash INP. Single-particle mass spectrometry was used to show that $33 \%$ of the ice crystal residues were "mineral dust/fly ash" and they then used electron microscopy to show that $20 \%$ of the particles in this category had a high degree of sphericity which indicated that they were fly ash. This is intriguing because $\sim 7 \%$ of the ice crystal residues were therefore fly ash. In addition, it should also be noted that their electron microscopy technique could not identify aerosolized irregular shaped bottom ash particles; hence, $7 \%$ is probably a lower limit for the contribution of combustion ash to the measurements of DeMott et al. (2003).

In addition, Sassen and Khvorostyanov (2008) report that particles associated with boreal fire smoke could nucleate ice and influence altocumulus clouds. They suggested that these particles could have been soil/dust particles, coated soot aerosol or organic material; we suggest that fly ash should also be considered as a possibility.

As a follow-up to this research, we propose that measurements are needed to constrain the abundance of combustion ashes in the atmosphere. A clear distinction needs to be made between mineral dust, fly ashes, and volcanic ashes by potentially using methods like magnetization and coercive field factors (Flanders, 1999; Xie and Dearing, 1999). The coercive field factor gives an indication of the percentage of fly ash that is airborne in relation to the total amount of magnetic material that is airborne. Other methods are isotopic labelling and back trajectory attribution. Isotopic labelling can be used during measurements by matching the spectra of the minerals in the atmosphere with the known isotopes characteristic of the possible sources of the measured particles. The back trajectory approach involves resolving the emission sources of combustion ashes and comparing to the emission route for natural dusts.

To ascertain the contribution of combustion ashes to tropospheric INPs and its impact on clouds, we also propose that further studies should focus on quantifying the effect of atmospheric processing and its implications for their ice nucleation abilities. This can give relevant information on the impact of freshly emitted and aged combustion ash particles. Lastly, the impact of these ashes on localized clouds (i.e. in the region of ash emission) may also be of interest for future assessment.

\section{The Supplement related to this article is available online at doi:10.5194/acp-15-5195-2015-supplement.}

Acknowledgements. The authors are grateful to Edward Mitchell for his assistance in generating some of the ash samples and James (Jim) McQuaid for helpful discussions on atmospheric measurements of aerosol particles. We acknowledge James Atkinson for his help in some of the calculations. We thank John N. Ward, Chairman of the American Coal Ash Association's Government Relations Committee, for helpful discussions on coal fly ash production. This project was funded by the European Research Council (FP7, 240449 ICE), the Natural Environment Research Council (NE/I020059/1, NE/I013466/1, NE/K004417/1) and the Engineering and Physical Science Research council (EPSRC EP/M003027/1). N. S. Umo acknowledges the Niger Delta Development Commission (NDDC) in Nigeria for financial assistance during his PhD studies (NDDC/DEHSS/2010PGFS/AK/011).

Edited by: H. Grothe

\section{References}

ACAA: Coal Ash Material Safety - a Health Risk-Based Evaluation of USGS Coal Ash Data from Five US Power Plants, American Coal Ash Association, Chelmsford, MA, 2012.

ACCA: Coal Combustion Products Production and Use Statistics by American Coal Ash Association, Advancing The Management and Use of Coal Combustion Products, Michigan, 2013.

Adriano, D. C., Page, A. L., Elseewi, A. A., Chang, A. C., and Straughan, I.: Utilization and disposal of fly ash and other coal 
residues in terrestrial ecosystems: a review, J. Environ. Qual., 9, 333-344, 1980.

Ansmann, A., Tesche, M., Seifert, P., Althausen, D., Engelmann, R., Fruntke, J., Wandinger, U., Mattis, I., and Müller, D.: Evolution of the ice phase in tropical altocumulus: samum lidar observations over Cape Verde, J. Geophys. Res.-Atmos., 114, D17208, doi:10.1029/2008JD011659, 2009.

Archuleta, C. M., DeMott, P. J., and Kreidenweis, S. M.: Ice nucleation by surrogates for atmospheric mineral dust and mineral dust/sulfate particles at cirrus temperatures, Atmos. Chem. Phys., 5, 2617-2634, doi:10.5194/acp-5-2617-2005, 2005.

Atkinson, J. D., Murray, B. J., Woodhouse, M. T., Whale, T. F., Baustian, K. J., Carslaw, K. S., Dobbie, S., O'Sullivan, D., and Malkin, T. L.: The importance of feldspar for ice nucleation by mineral dust in mixed-phase clouds, Nature, 498, 355-358, 2013.

Augustin-Bauditz, S., Wex, H., Kanter, S., Ebert, M., Niedermeier, D., Stolz, F., Prager, A., and Stratmann, F.: The immersion mode ice nucleation behavior of mineral dusts: a comparison of different pure and surface modified dusts, Geophys. Res. Lett., 41, 7375-7382, doi:10.1002/2014GL061317, 2014.

Basumajumdar, A., Das, A. K., Bandyopadhyay, N., and Maitra, S.: Some studies on the reaction between fly ash and lime, B. Mater. Sci., 28, 131-136, 2005.

Baustian, K. J., Cziczo, D. J., Wise, M. E., Pratt, K. A., Kulkarni, G., Hallar, A. G., and Tolbert, M. A.: Importance of aerosol composition, mixing state, and morphology for heterogeneous ice nucleation: A combined field and laboratory approach, J. Geophys. Res.-Atmos., 117, D06217, doi:10.1029/2011JD016784, 2012.

Baustian, K. J., Wise, M. E., Jensen, E. J., Schill, G. P., Freedman, M. A., and Tolbert, M. A.: State transformations and ice nucleation in amorphous (semi-)solid organic aerosol, Atmos. Chem. Phys., 13, 5615-5628, doi:10.5194/acp-13-5615-2013, 2013.

Block, C. and Dams, R.: Study of fly ash emission during combustion of coal, Environ. Sci. Technol., 10, 1011-1017, 1976.

Bond, T. C., Streets, D. G., Yarber, K. F., Nelson, S. M., Woo, J. H., and Klimont, Z.: A technology-based global inventory of black and organic carbon emissions from combustion, J. Geophys. Res.-Atmos., 109, D14203, doi:10.1029/2003JD003697, 2004.

Bond, T. C., Doherty, S. J., Fahey, D. W., Forster, P. M., Berntsen, T., DeAngelo, B. J., Flanner, M. G., Ghan, S., Kärcher, B., Koch, D., Kinne, S., Kondo, Y., Quinn, P. K., Sarofim, M. C., Schultz, M. G., Schulz, M., Venkataraman, C., Zhang, H., Zhang, S., Bellouin, N., Guttikunda, S. K., Hopke, P. K., Jacobson, M. Z., Kaiser, J. W., Klimont, Z., Lohmann, U., Schwarz, J. P., Shindell, D., Storelvmo, T., Warren, S. G., and Zender, C. S.: Bounding the role of black carbon in the climate system: a scientific assessment, J. Geophys. Res.-Atmos., 118, 5380-5552, 2013.

Broadley, S. L., Murray, B. J., Herbert, R. J., Atkinson, J. D., Dobbie, S., Malkin, T. L., Condliffe, E., and Neve, L.: Immersion mode heterogeneous ice nucleation by an illite rich powder representative of atmospheric mineral dust, Atmos. Chem. Phys., 12, 287-307, doi:10.5194/acp-12-287-2012, 2012.

Buhre, B. J. P., Hinkley, J. T., Gupta, R. P., Wall, T. F., and Nelson, P. F.: Submicron ash formation from coal combustion, Fuel, 84, 1206-1214, 2005.

Certini, G.: Effects of fire on properties of forest soils: a review, Oecologia, 143, 1-10, 2005.
Chen, H., Laskin, A., Baltrusaitis, J., Gorski, C. A., Scherer, M. M., and Grassian, V. H.: Coal fly ash as a source of iron in atmospheric dust, Environ. Sci. Technol., 46, 2112-2120, 2012.

Chen, Y., Shah, N., Huggins, F. E., and Huffman, G. P.: Transmission electron microscopy investigation of ultrafine coal fly ash particles, Environ. Sci. Technol., 39, 1144-1151, 2005.

Chimenos, J. M., Segarra, M., Fernández, M. A., and Espiell, F.: Characterization of the bottom ash in municipal solid waste incinerator, J. Hazard. Mater., 64, 211-222, 1999.

Connolly, P. J., Möhler, O., Field, P. R., Saathoff, H., Burgess, R., Choularton, T., and Gallagher, M.: Studies of heterogeneous freezing by three different desert dust samples, Atmos. Chem. Phys., 9, 2805-2824, doi:10.5194/acp-9-2805-2009, 2009.

Cziczo, D. J., Murphy, D. M., Hudson, P. K., and Thomson, D. S.: Single particle measurements of the chemical composition of cirrus ice residue during crystal-face, J. Geophys. Res.-Atmos., 109, D04201, doi:10.1029/2003JD004032, 2004.

Cziczo, D. J., Froyd, K. D., Hoose, C., Jensen, E. J., Diao, M., Zondlo, M. A., Smith, J. B., Twohy, C. H., and Murphy, D. M.: Clarifying the dominant sources and mechanisms of cirrus cloud formation, Science, 340, 1320-1324, 2013.

De Boer, A., Gjaltema, D., Hagedoorn, P., and Frijlink, H.: Characterization of inhalation aerosols: a critical evaluation of cascade impactor analysis and laser diffraction technique, Int. J. Pharm., 249, 219-231, 2002.

Del Monte, M. and Sabbioni, C.: Morphology and mineralogy of fly ash from a coal-fueled power plant, Arch. Meteor. Geophy. B, 35, 93-104, 1984.

DeMott, P. J.: An exploratory-study of ice nucleation by soot aerosols, J. Appl. Meteorol., 29, 1072-1079, 1990.

DeMott, P. J., Cziczo, D. J., Prenni, A. J., Murphy, D. M., Kreidenweis, S. M., Thomson, D. S., Borys, R., and Rogers, D. C.: Measurements of the concentration and composition of nuclei for cirrus formation, P. Natl. Acad. Sci. USA, 100, 14655-14660, 2003.

EPRI: Comparison of coal combustion products to other common materials: chemical characteristics, Electric Power Research Institute, 1020556, 21-26, 2010.

Fenelonov, V. B., Mel'gunov, M. S., and Parmon, V. N.: The properties of cenospheres and the mechanism of their formation during high-temperature coal combustion at thermal power plans, KONA, California, 1020556, 21-26, 2010.

Fitzpatrick, E. M., Jones, J. M., Pourkashanian, M., Ross, A. B., Williams, A., and Bartle, K. D.: Mechanistic aspects of soot formation from the combustion of pine wood, Energ. Fuel., 22, 3771-3778, 2008.

Flanders, P. J.: Identifying fly ash at a distance from fossil fuel power stations, Environ. Sci. Technol., 33, 528-532, 1999.

Forster, P., Ramaswamy, V., Artaxo, P., Berntsen, T., Betts, R., Fahey, D. W., Haywood, J., Lean, J., Lowey, D. C., Myhre, G., Nganga, J., Prinn, R., Raga, G., Schulz, M., and Van Dorland, R.: Changes in atmospheric constituents and in radiative forcing, in: Climate Change 2007: the Physical Science Basis, contribution of Working Group I to the Fourth Assess- ment Report of the Intergovernmental Panel on Climate Change, edited by: Solomon, S., Qin, D., Manning, M., Chen, Z., Marquis, M., Averyt, K. B., Tignor, M., and Miller, H. L., 28 pp., Cambridge University Press, Cambridge, UK, 2007. 
Friedman, B., Zelenyuk, A., Beranek, J., Kulkarni, G., Pekour, M., Gannet Hallar, A., McCubbin, I. B., Thornton, J. A., and Cziczo, D. J: Aerosol measurements at a high-elevation site: composition, size, and cloud condensation nuclei activity, Atmos. Chem. Phys., 13, 11839-11851, doi:10.5194/acp-13-11839-2013, 2013.

Gregg, S. and Sing, K.: Adsorption, Surface Area and Porosity, Academic Press London, UK, 303 pp., 1982.

Hader, J. D., Wright, T. P., and Petters, M. D.: Contribution of pollen to atmospheric ice nuclei concentrations, Atmos. Chem. Phys., 14, 5433-5449, doi:10.5194/acp-14-5433-2014, 2014.

Herbert, R. J., Murray, B. J., Whale, T. F., Dobbie, S. J., and Atkinson, J. D.: Representing time-dependent freezing behaviour in immersion mode ice nucleation, Atmos. Chem. Phys., 14, 85018520, doi:10.5194/acp-14-8501-2014, 2014.

Hiranuma, N., Augustin-Bauditz, S., Bingemer, H., Budke, C., Curtius, J., Danielczok, A., Diehl, K., Dreischmeier, K., Ebert, M., Frank, F., Hoffmann, N., Kandler, K., Kiselev, A., Koop, T., Leisner, T., Möhler, O., Nillius, B., Peckhaus, A., Rose, D., Weinbruch, S., Wex, H., Boose, Y., DeMott, P. J., Hader, J. D., Hill, T. C. J., Kanji, Z. A., Kulkarni, G., Levin, E. J. T., McCluskey, C. S., Murakami, M., Murray, B. J., Niedermeier, D., Petters, M. D., O'Sullivan, D., Saito, A., Schill, G. P., Tajiri, T., Tolbert, M. A., Welti, A., Whale, T. F., Wright, T. P., and Yamashita, K.: A comprehensive laboratory study on the immersion freezing behavior of illite NX particles: a comparison of 17 ice nucleation measurement techniques, Atmos. Chem. Phys., 15, 2489-2518, doi:10.5194/acp-15-2489-2015, 2015.

Hoose, C. and Möhler, O.: Heterogeneous ice nucleation on atmospheric aerosols: a review of results from laboratory experiments, Atmos. Chem. Phys., 12, 9817-9854, doi:10.5194/acp-12-98172012, 2012.

Hu, W. W., Hu, M., Yuan, B., Jimenez, J. L., Tang, Q., Peng, J. F., Hu, W., Shao, M., Wang, M., Zeng, L. M., Wu, Y. S., Gong, Z. H., Huang, X. F., and He, L. Y.: Insights on organic aerosol aging and the influence of coal combustion at a regional receptor site of central eastern China, Atmos. Chem. Phys., 13, 10095-10112, doi:10.5194/acp-13-10095-2013, 2013.

Jacobson, M. Z.: Effects of biomass burning on climate, accounting for heat and moisture fluxes, black and brown carbon, and cloud absorption effects, J. Geophys. Res.-Atmos., 119, 89809002, doi:10.1002/2014JD021861, 2014.

Jenkins, B. M., Baxter, L. L., Miles Jr., T. R., and Miles, T. R.: Combustion properties of biomass, Fuel Process. Technol., 54, 17-46, 1998.

Jewell, R. B. and Rathbone, R. F.: Optical properties of coal combustion byproducts for particle- size analysis by laser diffraction, Coal Combustion and Gasification Products, 1, 1-7, 2009.

Kamphus, M., Ettner-Mahl, M., Klimach, T., Drewnick, F., Keller, L., Cziczo, D. J., Mertes, S., Borrmann, S., and Curtius, J.: Chemical composition of ambient aerosol, ice residues and cloud droplet residues in mixed-phase clouds: single particle analysis during the Cloud and Aerosol Characterization Experiment (CLACE 6), Atmos. Chem. Phys., 10, 8077-8095, doi:10.5194/acp-10-8077-2010, 2010.

Kireeva, E. D., Popovicheva, O. B., Persiantseva, N. M., Khokhlova, T. D., and Shonija, N. K.: Effect of black carbon particles on the efficiency of water droplet freezing, Colloid J., 71, 353-359, 2009.
Kumai, M.: Snow crystals and the identification of the nuclei in the northern united-states of america, J. Meteorol., 18, 139-150, 1961.

Li, D. X. and Thomson, W. J.: Mullite formation kinetics of a singlephase gel, J. Am. Ceram. Soc., 73, 964-969, 1990.

Li, J., Posfai, M., Hobbs, P. V., and Buseck, P. R.: Individual aerosol particles from biomass burning in southern Africa: 2, compositions and aging of inorganic particles, J. Geophys. Res.-Atmos., 108, 8484, doi:10.1029/2002JD002310, 2003.

Liu, K.-C., Thomas, G., Caballero, A., Moya, J. S., and De Aza, S.: Mullite formation in kaolinite- $\alpha$-alumina, Acta Metall. Mater. 42, 489-495, 1994.

Li, W. and Shao, L.: Transmission electron microscopy study of aerosol particles from the brown hazes in northern China, J. Geophys. Res.-Atmos., 114, D09302, doi:10.1029/2008JD011285, 2009.

Li, W. J., Zhang, D. Z., Shao, L. Y., Zhou, S. Z., and Wang, W. $X .:$ Individual particle analysis of aerosols collected under haze and non-haze conditions at a high-elevation mountain site in the North China plain, Atmos. Chem. Phys., 11, 11733-11744, doi:10.5194/acp-11-11733-2011, 2011.

Mahlaba, J. S., Kearsley, E. P., and Kruger, R. A.: Microstructural and Mineralogical Transformation of Hydraulically Disposed Fly Ash-Implications to the Environment, Coal Combustion and Gasification Products, 4, 21-27, doi:10.4177/CCGP-D12-00001.1, 2012.

Malvern: A Basic Guide to Particle Characterization, Malvern Instruments Limited, Worcestershire, UK, 2012.

McCluskey, C. S., Demott, P. J., Prenni, A. J., Levin, E. J. T., Mcmeeking, G. R., Sullivan, A. P., Hill, T. C. J., Nakao, S., Carrico, C. M., and Kreidenweis, S. M.: Characteristics of atmospheric ice nucleating particles associated with biomass burning in the US: prescribed burns and wildfires, J. Geophys. Res.Atmos., 119, 10458-10470, doi:10.1002/2014JD021980, 2014.

Misra, M. K., Ragland, K. W., and Baker, A. J.: Wood ash composition as a function of furnace temperature, Biomass Bioenerg., 4, 103-116, 1993.

Murray, B. J., Broadley, S. L., Wilson, T. W., Bull, S. J., Wills, R. H., Christenson, H. K., and Murray, E. J.: Kinetics of the homogeneous freezing of water, Phys. Chem. Chem. Phys., 12, 1038010387, 2010a.

Murray, B. J., Wilson, T. W., Dobbie, S., Cui, Z. Q., Al-Jumur, S., Mohler, O., Schnaiter, M., Wagner, R., Benz, S., Niemand, M., Saathoff, H., Ebert, V., Wagner, S., and Karcher, B.: Heterogeneous nucleation of ice particles on glassy aerosols under cirrus conditions, Nature Geosci., 3, 233-237, 2010b.

Murray, B. J., Broadley, S. L., Wilson, T. W., Atkinson, J. D., and Wills, R. H.: Heterogeneous freezing of water droplets containing kaolinite particles, Atmos. Chem. Phys., 11, 4191-4207, doi:10.5194/acp-11-4191-2011, 2011.

Murray, B. J., O’Sullivan, D., Atkinson, J. D., and Webb, M. E.: Ice nucleation by particles immersed in supercooled cloud droplets, Chem. Soc. Rev., 41, 6519-6554, 2012.

Niedermeier, D., Hartmann, S., Shaw, R. A., Covert, D., Mentel, T. F., Schneider, J., Poulain, L., Reitz, P., Spindler, C., Clauss, T., Kiselev, A., Hallbauer, E., Wex, H., Mildenberger, K., and Stratmann, F.: Heterogeneous freezing of droplets with immersed mineral dust particles - measurements and parameterization, At- 
mos. Chem. Phys., 10, 3601-3614, doi:10.5194/acp-10-36012010, 2010.

Niemand, M., Möhler, O., Vogel, B., Vogel, H., Hoose, C., Connolly, P., Klein, H., Bingemer, H., Demott, P., Skrotzki, J., and Leisner, T.: A particle-surface-area-based parameterization of immersion freezing on desert dust particles, J. Atmos. Sci., 69, 3077-3092, 2012.

Nyambura, M. G., Mugera, G. W., Felicia, P. L., and Gathura, N. P.: Carbonation of brine impacted fractionated coal fly ash: implications for $\mathrm{CO}_{2}$ sequestration, J. Environ. Manage., 92, 655-664, 2011.

O’Sullivan, D., Murray, B. J., Malkin, T. L., Whale, T. F., Umo, N. S., Atkinson, J. D., Price, H. C., Baustian, K. J., Browse, J., and Webb, M. E.: Ice nucleation by fertile soil dusts: relative importance of mineral and biogenic components, Atmos. Chem. Phys., 14, 1853-1867, doi:10.5194/acp-14-1853-2014, 2014.

O'Sullivan, D., Murray, B. J., Ross, J. F., Whale, T. F., Price, H. C., Atkinson, J. D., Umo, N. S., and Webb, M. E.: The relevance of nanoscale biological fragments for ice nucleation in clouds, Scientific Reports, 5, 8082, doi:10.1038/srep08082, 2015.

Parungo, F., Ackerman, E., Proulx, H., and Pueschel, R.: Nucleation properties of fly ash in a coal-fired power-plant plume, Atmos. Environ., 12, 929-935, 1978.

Pereira, P. and Úbeda, X.: Spatial distribution of heavy metals released from ashes after a wild- fire, J. Environ. Eng. Landsc., 18, 13-22, 2010.

Petters, M. D., Parsons, M. T., Prenni, A. J., Demott, P. J., Kreidenweis, S. M., Carrico, C. M., Sullivan, A. P., Mcmeeking, G. R., Levin, E., Wold, C. E., Collett, J. L., and Moosmuller, H.: Ice nuclei emissions from biomass burning, J. Geophys. Res.-Atmos., 114, 148-227, doi:10.1029/2008JD011532, 2009.

Popovicheva, O., Kireeva, E., Persiantseva, N., Khokhlova, T., Shonija, N., Tishkova, V., and Demirdjian, B.: Effect of soot on immersion freezing of water and possible atmospheric implications, Atmos. Res., 90, 326-337, 2008.

Pósfai, M., Simonics, R., Li, J., Hobbs, P. V., and Buseck, P. R.: Individual aerosol particles from biomass burning in Southern Africa: 1. Compositions and size distributions of carbonaceous particles, J. Geophys. Res.-Atmos., 108, 8483, doi:10.1029/2002JD002291, 2003.

Posfai, M., Gelencser, A., Simonics, R., Arato, K., Li, J., Hobbs, P. V., and Buseck, P. R.: Atmospheric tar balls: particles from biomass and biofuel burning, J. Geophys. Res.-Atmos., 109, D06213, doi:10.1029/2003JD004169, 2004.

Pratt, K. A., Demott, P. J., French, J. R., Wang, Z., Westphal, D. L., Heymsfield, A. J., Twohy, C. H., Prenni, A. J., and Prather, K. A.: In situ detection of biological particles in cloud ice-crystals, Nat. Geosci., 2, 398-401, 2009.

Pratt, K. A., Heymsfield, A. J., Twohy, C. H., Murphy, S. M., Demott, P. J., Hudson, J. G., Subramanian, R., Wang, Z., Seinfeld, J. H., and Prather, K. A.: In situ chemical characterization of aged biomass-burning aerosols impacting cold wave clouds, J. Atmos. Sci., 67, 2451-2468, 2010.

Raison, R. J., Khanna, P. K., and Woods, P. V.: Mechanisms of element transfer to the atmo- sphere during vegetation fires, Can. J. Forest Res., 15, 132-140, 1985.

Richardson, M. S., DeMott, P. J., Kreidenweis, S. M., Cziczo, D. J., Dunlea, E. J., Jimenez, J. L., Thomson, D. S., Ashbaugh, L. L., Borys, R. D., Westphal, D. L., Casuccio, G. S.,
Lersch, T. L.: Measurements of heterogeneous ice nuclei in the western united states in spring-time and their relation to aerosol characteristics, J. Geophys. Res.-Atmos., 112, D02209, doi:10.1029/2006JD007500, 2007.

Riechers, B., Wittbracht, F., Hutten, A., and Koop, T.: The homogeneous ice nucleation rate of water droplets produced in a microfluidic device and the role of temperature uncertainty, Phys. Chem. Chem. Phys., 15, 5873-5887, 2013.

Sassen, K. and Khvorostyanov, V. I.: Cloud effects from boreal forest fire smoke: Evidence for ice nucleation from polarization lidar data and cloud model simulations, Environ. Res. Lett., 3, 025006, doi:10.1088/1748-9326/3/2/025006, 2008.

Schnell, R. C., Van Valin, C. C., and Pueschel, R. F.: Atmospheric ice nuclei: no detectable effects from a coal-fired powerplant plume, Geophys. Res. Lett., 3, 657-660, 1976.

Spracklen, D. V., Carslaw, K. S., Pöschl, U., Rap, A., and Forster, P. M.: Global cloud condensation nuclei influenced by carbonaceous combustion aerosol, Atmos. Chem. Phys., 11, 9067-9087, doi:10.5194/acp-11-9067-2011, 2011.

Tobo, Y., DeMott, P. J., Hill, T. C. J., Prenni, A. J., SwobodaColberg, N. G., Franc, G. D., and Kreidenweis, S. M.: Organic matter matters for ice nuclei of agricultural soil origin, Atmos. Chem. Phys., 14, 8521-8531, doi:10.5194/acp-14-8521-2014, 2014.

USEPA: Coal-Clean Energy-US EPA, Washington DC and United States Environmental Protection Agency (USEPA), 2012.

Vali, G.: Quantitative evaluation of experimental results an the heterogeneous freezing nucleation of supercooled liquids, J. Atmos. Sci., 28, 402-409, 1971.

Vali, G.: Nucleation terminology, J. Aerosol Sci., 16, 575-576, 1985.

Vali, G.: Interpretation of freezing nucleation experiments: singular and stochastic; sites and surfaces, Atmos. Chem. Phys., 14, 5271-5294, doi:10.5194/acp-14-5271-2014, 2014.

Vassilev, S. V., Baxter, D., Andersen, L. K., and Vassileva, C. G.: An overview of the composition and application of biomass ash. Part 1. Phase-mineral and chemical composition and classification, Fuel, 105, 40-76, 2013a.

Vassilev, S. V., Baxter, D., Andersen, L. K., and Vassileva, C. G.: An overview of the composition and application of biomass ash: Part 2. Potential utilisation, technological and ecological advantages and challenges, Fuel, 105, 19-39, 2013b.

Wang, X., Williams, B. J., Wang, X., Tang, Y., Huang, Y., Kong, L., Yang, X., and Biswas, P.: Characterization of organic aerosol produced during pulverized coal combustion in a drop tube furnace, Atmos. Chem. Phys., 13, 10919-10932, doi:10.5194/acp13-10919-2013, 2013.

WCA: Coal Combustion Products Report, World Coal Association, London, 2013.

Westerling, A. L., Hidalgo, H. G., Cayan, D. R., and Swetnam, T. W.: Warming and earlier spring increase western US forest wildfire activity, Science, 313, 940-943, 2006.

Whale, T. F., Murray, B. J., O’Sullivan, D., Umo, N. S., Baustian, K. J., Atkinson, J. D., and Morris, G. J.: A technique for quantifying heterogeneous ice nucleation in microlitre supercooled water droplets, Atmos. Meas. Tech. Discuss., 7, 95099536, doi:10.5194/amtd-7-9509-2014, 2014.

Wex, H., DeMott, P. J., Tobo, Y., Hartmann, S., Rösch, M., Clauss, T., Tomsche, L., Niedermeier, D., and Stratmann, F.: Kaolinite 
particles as ice nuclei: learning from the use of different kaolinite samples and different coatings, Atmos. Chem. Phys., 14, 55295546, doi:10.5194/acp-14-5529-2014, 2014.

Williams, A., Jones, J. M., Ma, L., and Pourkashanian, M.: Pollutants from the combustion of solid biomass fuels, Prog. Energ. Combust., 38, 113-137, 2012.

Wilson, T. W., Murray, B. J., Wagner, R., Möhler, O., Saathoff, H., Schnaiter, M., Skrotzki, J., Price, H. C., Malkin, T. L., Dobbie, S., and Al-Jumur, S. M. R. K.: Glassy aerosols with a range of compositions nucleate ice heterogeneously at cirrus temperatures, Atmos. Chem. Phys., 12, 8611-8632, doi:10.5194/acp-128611-2012, 2012.
Xie, S. and Dearing, J. A.: Comment on "Identifying fly ash at a distance from fossil fuel power stations", Environ. Sci. Technol., 33, 4140-4140, 1999.

Zhang, Y., Schauer, J. J., Zhang, Y., Zeng, L., Wei, Y., Liu, Y., and Shao, M.: Characteristics of particulate carbon emissions from real-world chinese coal combustion, Environ. Sci. Technol., 42, 5068-5073, 2008. 